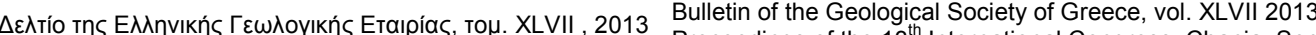
Proceedings of the $13^{\text {th }}$ International Congress, Chania, Sept.

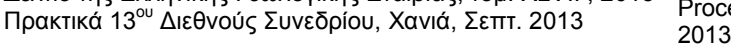

\title{
GENESIS OF ALPINOTYPE FISSURE MINERALS FROM THASOS ISLAND, NORTHERN GREECE - MINERALOGY, MINERAL CHEMISTRY AND CRYSTALLIZING ENVIRONMENT
}

\author{
Voudouris P. ${ }^{1}$, Constantinidou S. $^{1}$, Kati M. ${ }^{1}$, Mavrogonatos C. ${ }^{1}$, \\ Kanellopoulos $\mathbf{C}^{1}{ }^{1}$ and Volioti $\mathbf{E}^{1}$. \\ ${ }^{I}$ National and Kapodistrian University of Athens, Faculty of Geology and Geoenvironment, De- \\ partment of Mineralogy and Petrology,voudouris@geol.uoa.gr, geokonstantinidou@gmail.com, \\ kati@geol.uoa.gr,kmavrogon@geol.uoa.gr,ckanellopoulos@gmail.com.
}

\begin{abstract}
Alpinotype fissure-minerals in Thasos Island are hosted in gneisses, amphibolites, Mn-rich schists and calc-silicate layers, and marbles of the Carboniferous-Permian Pangeon Unit, which represents the lower tectonostratigraphic unit of the southern Rhodope metamorphic core complex. Alpinotype fissures crosscut metamorphic fabrics and are closely related to the exhumation processes of the core complex during the Oligocene-Miocene. Most mineralized fissures occur close to a major detachment fault, which separates gneisses from marbles and amphibolites. The mineralogy of the alpinotype fissures is closely related to the host rocks: amphibolite-hosted fissures include adularia, albite, quartz, titanite, apatite, actinolite, chlorite, calcite, hematite and rutile. Fissures in para- and orthogneisses- and in metapegmatites are characterized by smoky and clear quartz, adularia, muscovite and hematite. Fissures within spessartite-piemontite schists contain quartz, chlorite, spessartite, hematite, rutile, albite, epidote and traces of zircon. Finally fissures in calc-silicate layers include Mn-grossular, quartz and Mn-clinozoisite. Hydrothermal alteration halos surrounding the fissures may suggest leaching of the wall rocks as a potential mechanism for mineral deposition. Scepter quartz crystals consist of a lower Tessinhabit crystal and several generations of upper prismatic quartz crystals, suggesting several stages of crystallization and changing P-T-x conditions with time. Chlorite geothermometry indicates temperatures of formation in the range between 286 and $366^{\circ} \mathrm{C}$. Tessin habit quartz was deposited from $\mathrm{CO}_{2}$-bearing fluids, probably at the transition from a compressional to an extensional tectonic regime and was later dissolved by meteoric water dominated fluids resulting in the formation of quartz scepters. Oxidizing conditions are indicated by the widespread occurrence of hematite in the mineralization. The studied area represents a unique mineralogical geotope. Its geological-mineralogical heritage should be protected through establishment of a mineralogical-petrological geopark that will also promote sustainable development of the area.
\end{abstract}

Key words: Alpinotype fissure-minerals, Thasos island, Rhodope.

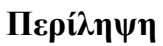

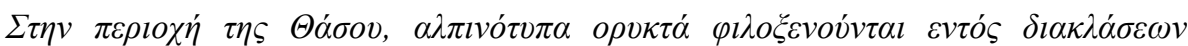

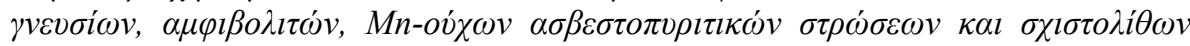

XLVII. No $1-468$ 


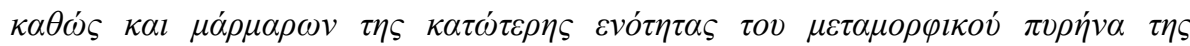

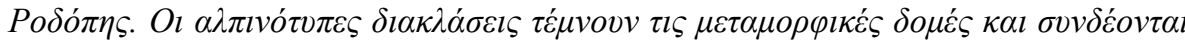

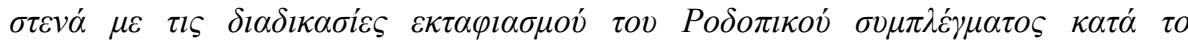

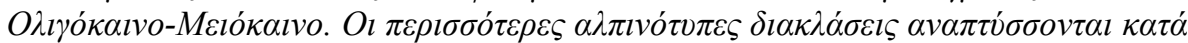

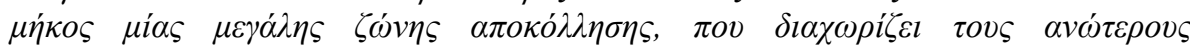

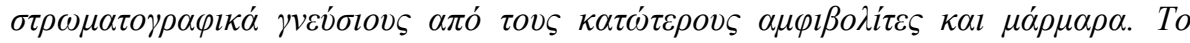

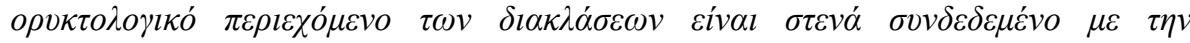

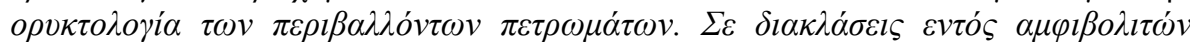

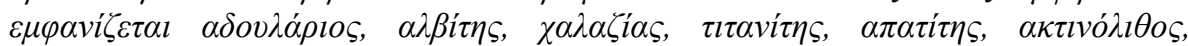

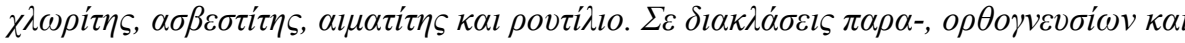

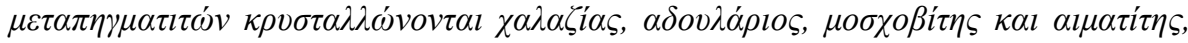

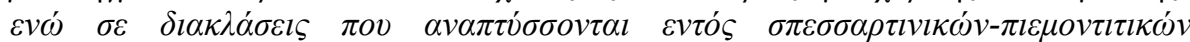

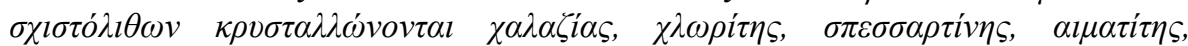

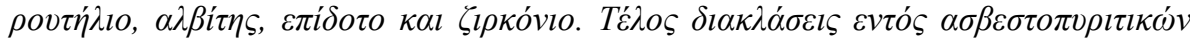

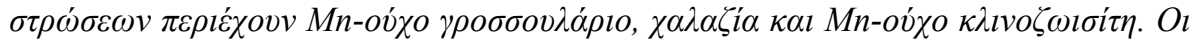

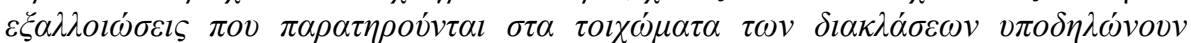

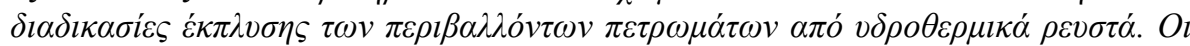

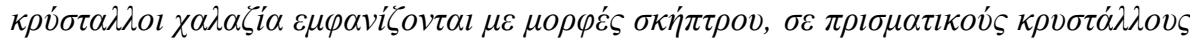

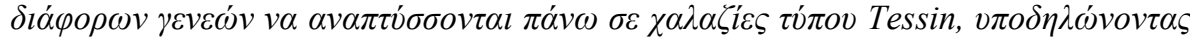

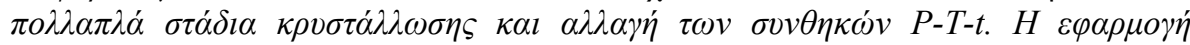

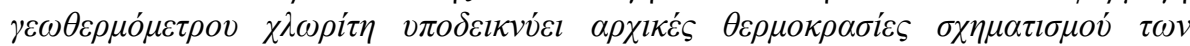

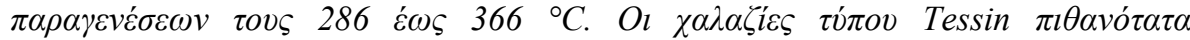

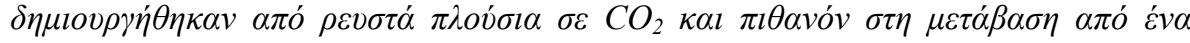

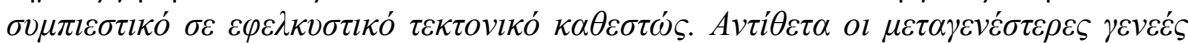

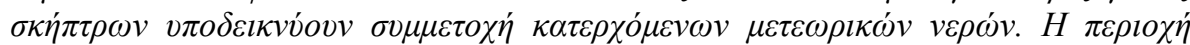

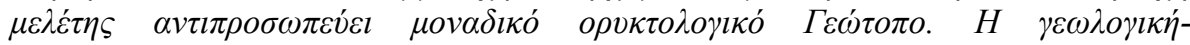

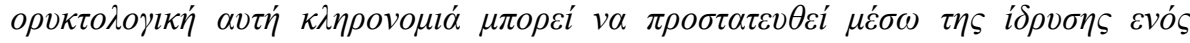

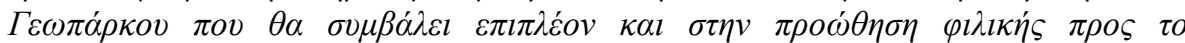
$\pi \varepsilon \rho \imath \beta \alpha ́ \lambda \lambda o v \alpha v \alpha \dot{\pi} \tau v \xi \xi \varsigma \tau \eta \varsigma \Theta \alpha ́ \sigma o v$.

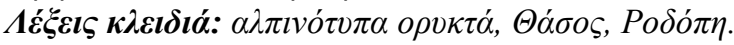

\section{Introduction}

Alpinotype fissure minerals occur in several regions in the world with alpine-type, late-stage collisional tectonics such as the Alps, Himalaya, as well as in older orogens like the polar Urals, Norway, USA, and Brazil (Stalder, 1964; Stalder and Touray, 1970; Mullis, 1988, 1996; Niedermayer, 1993). These minerals, usually in large euhedral crystals, occur in fissure veins, crosscutting the metamorphic fabric of the host rocks. Their formation took place after the peak metamorphic conditions and continued during the retrograde paths of orogenic evolution under transpressional, transtensional and finally to post-kinematic extensional conditions, during the late neo-Alpine tectonometamorphic phase of the Alpine evolution (Stalder and Touray, 1970; Mullis, 1988, 1996). Over the last two decades, Greece became a well-established alpinotype mineral province (Niedermayer, 1993; Wendel and Kapelas, 1996; Voudouris et al., 2004), where large, euhedral crystals of alpine-type quartz, are reported from Crete Island, Attica, Evia and Thasos Islands (Voudouris et al., 2004; Voudouris, 2005; Tsolakos et al., 2008; Maneta and Voudouris, 2010). Usually alpinotype fissures are characterized by mineralogical-geochemical zonation, with an external zone consisting of fresh host rock, grading inward to altered rocks, then to a monomineralic massive quartz zone and finaly to so-called alpine fissure that is characterized by very well crystallized minerals (Kandutsch and Wachtler, 2000). The above outward zonation is the result of gradually cooling hydrothermal solutions. The crystals are deposited on the quartz layer and grow with their greatest dimension perpendicular to the empty space of the fissure. The aim of the present study is to describe the mode of occurrence of alpinotype fissure minerals at Thasos Island and to present a

$\underline{\text { XLVII. No } 1-469}$ 
possible genetic model, based predominantly on the mineralogy, mineral chemistry and paragenetic relations.

\section{Geology}

Thasos Island consists mainly of low to medium grade metamorphic rocks of the Pangeon Unit, which is the lower tectonic unit of the Rhodope metamorphic complex (Brun and Sokoutis, 2007). The main lithological units of Thasos, from base to top, are (Brun and Sokoutis, 2007): (1) a lower unit consisting of marbles with intercalations of paragneisses and micaschists, (2) an intermediate unit consisting of orthogneisses, marbles with some intercalations of paragneisses, mica-schists and numerous amphibolite bodies, (3) an upper unit consisting of migmatites and gneisses. In places, the alpine sequence is unconformably covered by unmetamorphosed Neogene conglomerates. At least three major tectonic phases have affected these lithologies (Brun and Sokoutis, 2007): (a) a compressional phase (pre mid-Eocene), resulted to the thrusting of the gneisses/migmatites and the overlying marbles on top of the lower marble unit; (b) extensional ductile to brittle deformation (from mid-Eocene to mid-Miocene times) resulted to NE- trending st retching lineation, foliated fabric, and widespread boudinage formation; (c) Late Miocene normal faulting is responsible for the development of km-scale tilted blocks of rocks in the SW part of the island.

Alpinotype fissures on Thasos Island are developed in both the lower and intermediate units, and mainly controlled by a major thrust/detachment fault that separates these lithological units. The fissure veins at Thasos are elongate or sigmoidal, usually corresponding to systems of en echelon tensional gashes, and are developed as lens-like bodies perpendicular to the metamorphic rock fabric (Figure 1a to g). Their thickness varies between a few $\mathrm{cm}$ and about $2 \mathrm{~m}$. Their length ranges between 1 and $5 \mathrm{~m}$. An alteration halo surrounds the fissure veins including leached rock, which is then rimmed by the unaltered, fresh rock (Figure 1a). The mineralogy of fissure veins at Thasos is related to the composition of the host rocks: Alpinotype minerals in amphibolite-hosted fissures (Figure 1a to d) include amphibole, albite, adularia, titanite, chlorite, tourmaline, epidote, quartz, biotite, hematite, rutile and zircon. Fissures within spessartine-piemontite schists (Figure 1e) contain quartz, chlorite, spessartine, hematite, rutile, adularia, epidote and traces of zircon. Fissures hosted within Mn-rich calc-silicate layers contain Mn-clinozoisite, Mn-grossular and smoky quartz (Figure 1f). Finally ortho-, paragneiss- and metapegmatite-hosted fissures contain smoky quartz, muscovite, hematite, adularia, ilmenite and rutile (Figure $1 \mathrm{~g}$ to i).

\section{Materials and Methods}

Fourty thin sections were studied by optical microscopy. A total of fifteen thin-and-polished sections were studied by scanning slectron microscopy (SEM-EDS) using a Jeol JSM 5600 SEM instrument, equipped with an Oxford ISIS 300 OXFORD system, with the following operating conditions: accelerating voltage $20 \mathrm{kV}$, beam current $0.5 \mathrm{nA}$, time of measurement $50 \mathrm{sec}$ and beam diameter 1-2 $\mu \mathrm{m}$. The spectra were processed using the ZAF program (3interactions). In addition, XRD analyses were carried out using a Siemens (Brooker) 5005 X-ray Diffractometer. Operating conditions were as follows: $\mathrm{Cu} \mathrm{Ka}$ radiation at $40 \mathrm{kV}, 40 \mathrm{nA}, 0.020^{\circ}$ step size and $1.0 \mathrm{~s}$ step time. The XRD patterns were evaluated using the EVA v.10.0 program of the Siemens DIFFRACplus and the D5005 software package. All samples were studied at the laboratories of the Department of Geology and Geoenvironment, University of Athens.

\section{Mineralogy and Mineral Chemistry}

Quartz is the most abundant mineral in Thasos occuring in a variety of crystal forms and combinations (rock crystal, smoky quartz, prase). The green colour of prase (Figure 1b) is due to chlorite and actinolite inclusions. The color of smoky quartz varies from pale brown, brown-black to dark black. The majority of the quartz crystals show a Tessin habit (Figure 1c). Scepter crystals (several

$\underline{\text { XLVII. No } 1-470}$ 
scepter generations with prismatic habit, Figure 1i) occur as overgrowth on a basal Tessin habit crystal.

Garnet group minerals are found in fissures hosted by spessartite-piemontite schists (Figures 1e and 2a) and by clinozoisite-grossular-rich calc-silicate layers (Figure 1f) Electron microprobe analyses demonstrate that garnets from fissures within the spessartite-piemontite schists are spessartite, with 26.55 to 32.57 wt. \% MnO (Table 1, Figure 3a). Pale yellow transparent Mn-rich grossular up to $0.3 \mathrm{~cm}$, were also identified in clinozoisite-grossular fissures crosscutting Mn-rich calc-silicate layers (Figure 1f). They contain up to $3.6 \mathrm{wt}$. \% $\mathrm{MnO}$.

Chlorite is a common constituent in fissures of piemontite-spessartite schists and in amphibolites, where it is associated with quartz, spessartite, albite, adularia, muscovite, rutile, zircon, titanite, epidote, hematite and calcite (Figures 1b, c, e and 2a to e). It forms dark green pseudo-hexagonal crystals up to $3 \mathrm{~cm}$. Green quartz from amphibolite-hosted fissures includes wormy chlorite and sylvine crystals (Figure 2d). Chlorite from the spessartite-piemontite schists (rhipidolite and clinochlore) contain more $\mathrm{MgO}$ (up to $30.2 \mathrm{wt}$ \%) and $\mathrm{MnO}$ (up to $1.4 \mathrm{wt}$ \%) and less $\mathrm{FeO}$ (up to 5.4 wt. \%) compared to chlorites from the amphibolitic host rocks (clinochlore and pycnochlorite) (Table 1; Figure 3b). Using the chlorite geothermometer of Cathelineau (1988), it is suggested that the chlorites in amphibolite-hosted fissures were formed at temperatures between 315 and $366{ }^{\circ} \mathrm{C}$. The Mn-rich chlorites from the spessartite-piemontite schists were formed at temperatures ranging from 286 to $305^{\circ} \mathrm{C}$.

Feldspar group minerals are abundant in the alpinotype fissures from Thasos Island Sodium-rich members (e.g. albite and oligoclase) occur in both piemontite-spessartite schists and amphibolites and are absent from the gneisses (Figures 2b, e and 3c). Albite crystals are translucent or milky colored and often twinned. Adularia (hydrothermal variety of K-feldspar), in translucent milky (up to $1 \mathrm{~cm}$ ) crystals, occurs in all studied fissures. Adularia coexists with hematite, titanite, quartz, chlorite and spessartite, in the fissures of amphibolites and piemontite-spessartite schists (Figures 1d, e and 2 b, d, e). Paragneiss-, orthogneiss- and metapegmatite-hosted fissures contain adularia in association with smoky quartz, sometimes twinned after the Manebach and Baveno laws. Adularia contains up to 0.5 wt. $\% \mathrm{BaO}$ in the structure (Table 1).

Epidote group minerals occur (a) in fissures hosted in piemontite-spessartite schists (Figure 2a), (b) in amphibolite-hosted fissures together with chlorite forming radial aggregates of idiomorphic green crystals up to $4 \mathrm{~cm}$ in size, and (c) pink-red coloured epidote-clinozoisite in fissures hosted by clinozoisite-grossular calc-silicate layers (Figure 1f). Electron microprobe analyses are presented in Table 1 and the results are plotted in Figure 3(d, e). Some epidotes-clinozoisites from the amphibolite-hosted fissures are characterized by relatively high $\mathrm{Ce}_{2} \mathrm{O}_{3}, \mathrm{Sc}_{2} \mathrm{O}_{3}$ and $\mathrm{Cr}_{2} \mathrm{O}_{3}$ contents (up to 4.4 wt. \%, $1.2 \mathrm{wt}$. \%, and $3.6 \mathrm{wt}$ \% respectively). The fissures in the piemontite-spessartite schists contain epidote with up to 2.3 wt. $\% \mathrm{Mn}_{2} \mathrm{O}_{3}$. The Ce-, $\mathrm{Cr}$ - and Sc-rich epidotes have lower percentage of $\mathrm{Al}$ (1.8 to $2.0 \mathrm{apfu}$ ) compared to all other epidotes (2.2-2.4 Al apfu), due to the substitution of trivalent $\mathrm{Al}$ by $\mathrm{Ce}, \mathrm{Cr}$ and $\mathrm{Sc}$ (Table 1; Figure 3d). The pink-red colored epidotes from the clinozoisite-grossular calc-silicate layers have low $\mathrm{Mn}_{2} \mathrm{O}_{3}$ content (up to 0.56 wt. \%; Table 1).

Muscovite is present in minor amounts in amphibolite-hosted fissures (Figure 2b, c). It mainly occurs in gneiss- and metapegmatite-hosted fissures, where it is intergrown with smoky and clear quartz forming pseudohexagonal crystals, up to $2 \mathrm{~cm}$ (Figure 1h).

Phlogopite occurs in minor amounts in the amphibolite-hosted fissures. Electron microprobe analyses (Table 1), indicate low $\mathrm{TiO}_{2}$ probably in accordance to its hydrothermal origin.

Titanite forms olive-green-to yellow transparent crystals up to $0.3 \mathrm{~cm}$. It accompanies adularia, quartz and chlorite in amphibolite-hosted fissures (Figures $1 \mathrm{~d}$ and $2 \mathrm{a}, \mathrm{e}$ ).

Tourmaline is present in amphibolite-hosted fissures and forms black crystals up to $4 \mathrm{~cm}$ length. It is intergrown with chlorite, titanite and quartz. 
Hematite iron roses, up to $5 \mathrm{~cm}$ in size, occur in amphibolite-hosted fissures (Figure 2c). Hematite is also abundant in piemontite-spessartite schists (Figures $1 \mathrm{e}$ and $2 \mathrm{~b}$ ). In gneiss- and metapegmatite-hosted fissures, hematite is intergrown with smoky quartz and adularia.

Rutile needles up to $1 \mathrm{~cm}$ in length occur in amphibolite-hosted fissures together with hematite, chlorite and quartz. They are usually enclosed, and/or intergrown with hematite (Figure 2c) considered to be the products of $\mathrm{TiO}_{2}$ exsolution from previous ilmenite.

Calcite is present as euhedral crystals up to $4 \mathrm{~cm}$ in amphibolite-hosted fissures. They are often hydrothermally corroded and accompany chlorite and quartz (Figure 1c).

Amphibole, apatite, zircon, sylvine and barite are observed only under the microscope (Figure 2) and are minor fissure minerals at Thasos. Electron microprobe analyses of amphibole are given in Table 1 and the data are plotted in the magnesio-hornblende field of Figure $3 \mathrm{f}$.
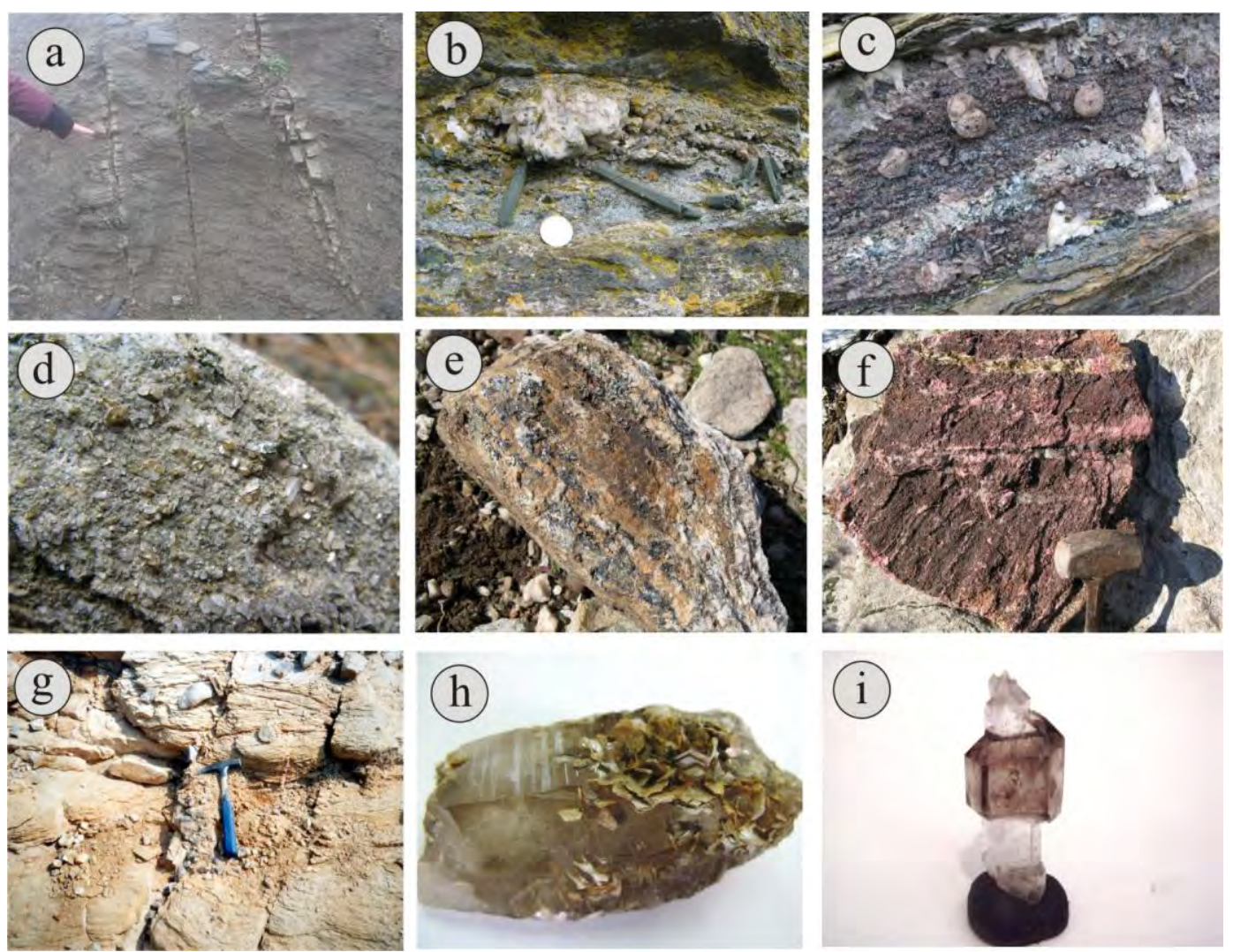

Figure 1 - (a) Amphibolite-hosted fissures with well-formed bleached alteration halo (white area). (b, c) Amphibolite-hosted fissures with euhedral crystals of Tessin habit chloritized quartz, clear quartz, hematite, calcite and chlorite. (d) Titanite and adularia coating the walls of an amphibolite-hosted fissure. (e) Hematite, spessartite, adularia and chlorite coating the wall of fissure of piemontite-spessartite schist. (f) fissures with manganese clinozoisite, quartz and grossular within a Mn-rich calc-silicate layer. (g) Orthogneiss-hosted fissures with smoky quartz. (h) smoky quartz associated with muscovite. (i) Three generations of prismatic quartz scepter. 

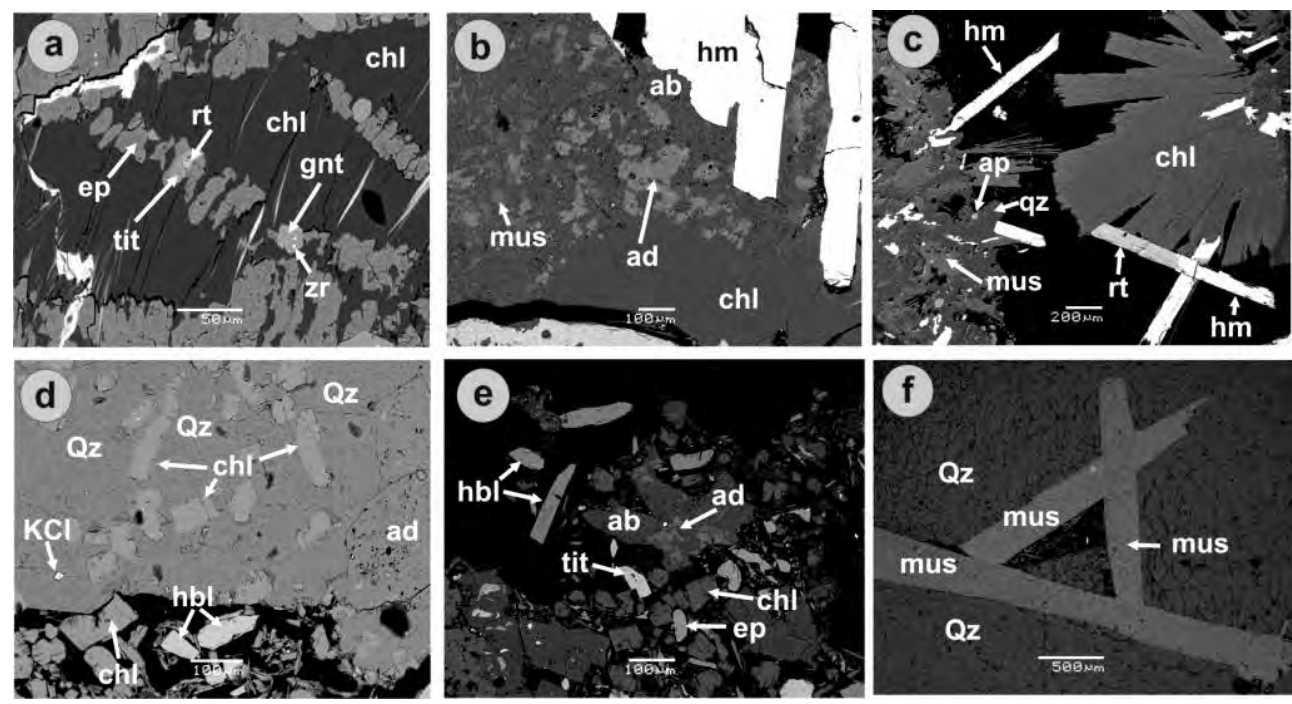

Figure 2 - Photomicrographs demonstrating mineralogical assemblages of alpine fissure content at Thasos (SEM-BSE images). (a,b) Piemontite-spessartite schist-hosted fissures containing chlorite (chl), garnet (gnt), hematite (hm), rutile (rt), albite (ab), adularia (ad), muscovite (mus), epidote (ep). The garnet and epidote crystals contain tiny zircon (zr) inclusions. (c to

e) Amphibolite-hosted fissures with chlorite (chl), hematite (hm), epidote (ep), muscovite (mus), albite (ab), titanite (tit), albite (ab), adularia (ad), rutile (rt), quartz (qz), apatite (ap), amphibole (hbl) and sylvine (KCl). (f) Muscovite (mus) included in smoky quartz (qz) from a gneiss-hosted fissure.
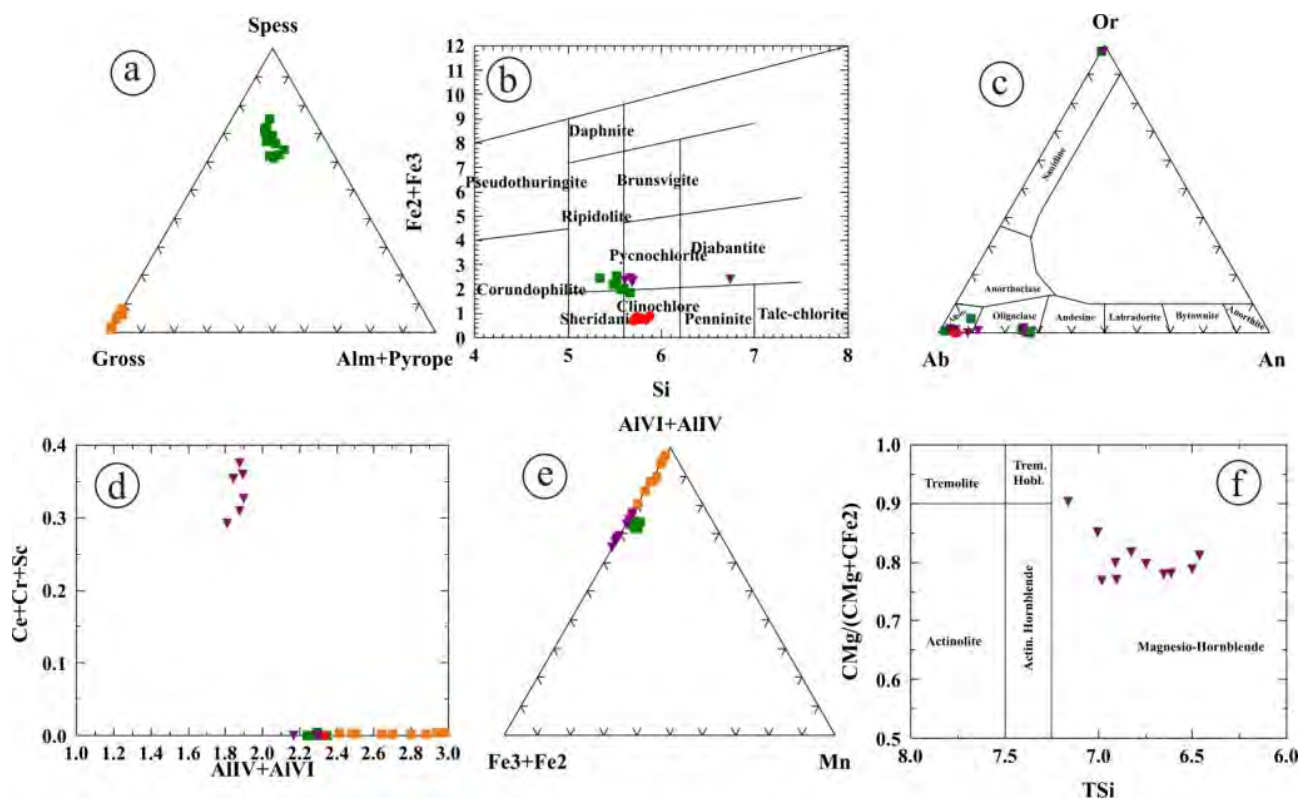

Figure 3 - (a) Compositions of garnet group minerals plotted in the Spess-Gross-

(Alm+Pyrope) ternary diagram. (b) Compositions of chlorite plotted in the $\mathrm{Si}-\left(\mathrm{Fe}^{2+}+\mathrm{Fe}^{3+}\right)$ discrimination diagram. (c) Analysed feldspars plotted in the Or-Ab-An discrimination diagram. (d,e) Compositions of epidote plotted in the $\mathrm{Al}-(\mathrm{Ce}+\mathrm{Cr}+\mathrm{Sc})$ and $\mathrm{Al}-\left(\mathrm{Fe}^{3+}+\mathrm{Fe}^{2+}\right)-\mathrm{Mn}$ and (f) Composition of hornblende. (Green squares = piemontite-spessartite quartzite, red bullets and purple triangles $=$ metabasite, orange squares $=$ Mn-rich calc-silicate layers). 


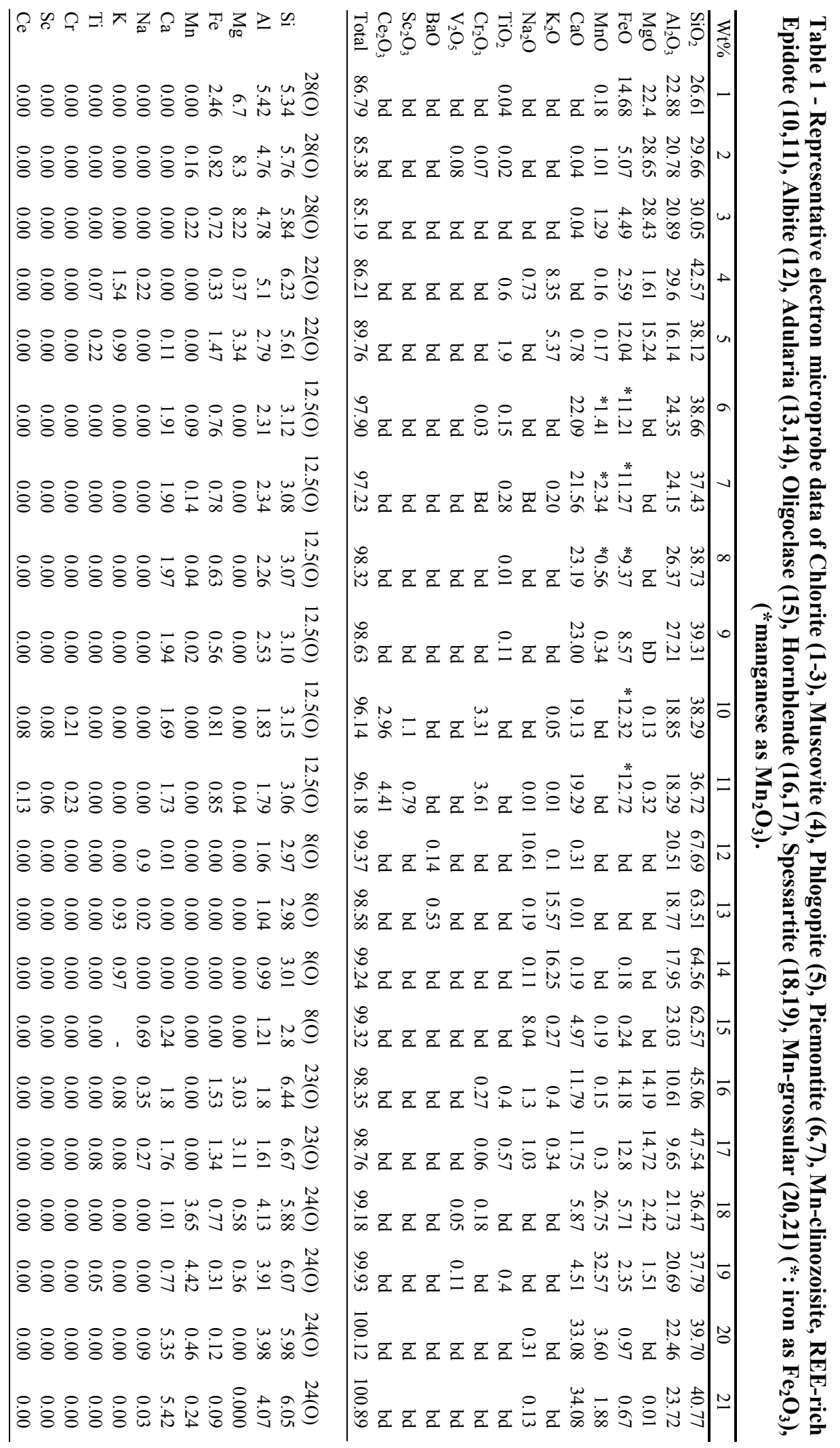




\section{Discussion}

Previous work on alpinotype fissure vein mineralization suggest that their formation started after the peak metamorphic conditions and is mainly related to retrograde evolution from fluid circulation during the final stages of continental collision (Mullis et al., 1994). In Thasos Island, the formation of alpinotype fissures is closely related to the exhumation of the Southern Rhodope Metamorphic Core Complex during the Oligocene-Miocene (Brun and Sokoutis, 2007). At Thasos the mineralized extensional fissures occur close to the thrust fault separating the lower from the intermediate units and are probably related to a reactivation of this fault as a low-angle detachment during the exhumation stage (Brun and Sokoutis, 2007).

The presence of various forms of quartz, even in the same fissure, indicates several stages of deposition under fluctuating hydrothermal conditions. Changes in pressure, temperature and fluid composition, may have caused the variation in the observed mineralogical assemblages. Following initial deposition of Tessin-habit quartz crystals, later inputs of hydrothermal fluids in the fissures, resulted in partial dissolution of Tessin-habit crystals (under formation of skeletal quartz), overgrowths of scepter crystals, and/or intergrowth with several minerals as for example chlorite, muscovite, etc. The wallrock alteration halo surrounding the alpinotype fissures, suggest hydothermal leaching of chemical components from the host rocks and their contribution within the fissures, as already proposed by Niedermayer (1993).

The minerals within the alpinotype fissures of Thasos were probably started to form at temperatures between about $370^{\circ}$ and $290^{\circ} \mathrm{C}$, as indicated by the geothermometry of chlorite associated with Tessin-habit quartz. Fluid inclusion data are not yet available for Thasos quartz, but the above temperatures are quite close to those obtained from fluid inclusion data of similar Tessin-habit smoky quartz at the neighboring Dassoto, Drama area ( $\mathrm{T}_{\mathrm{h}}$ between 300 and $380{ }^{\circ} \mathrm{C}$; Melfos and Voudouris, 2006). This temperarute range also fits very well to crystallization temperatures from Tessin-habit quartz from the Kavala, intrusion-related Bi-Te-Au deposit (Fornadel et al., 2011).

It has been suggested by Stalder and Touray (1970), Mullis (1975) and Mullis et al. (1994, 2001) that Tessin-habit quartz in the Alps can only be formed under high $f \mathrm{CO}_{2}$ values of the hyodrothermal solutions. This is in accordance with available data from Dassoto and Kavala, where $\mathrm{CO}_{2}$ bearing fluid inclusions occur in the Tessin-habit crystals (Melfos and Voudouris, 2006; Melfos et al., 2008; Fornadel et al., 2011). $\mathrm{CO}_{2}$-bearing fluid must have prevailed during crystallization of Tessin-habit quartz in Thasos island and this should have taken place in the transition from a compressional to an extensional tectonic regime, as is the case in the central Alps (Heijboer, 2006; Heijboer et al., 2003). Late incursion of meteoric and/or seawater at depth may have caused the crystallization of the prismatic-habit quartz scepters at lower temperatures from $\mathrm{NaCl}$ - and $\mathrm{KCl}$-bearing hydrothermal fluids (as suggested by Mullis et al., 1994).

Thasos Island (and Dassoto area of Drama) is to our knowledge a unique case among the Alpine fissure occurrences in Europe, where two types of quartz crystals (with both prismatic and Tessin-habit) coexist in the same fissure. Usually in the Alps these two types of quartz crystals occur in different fissures, as a result of deposition under different stress fields (Heijboer, 2006; Heijboer et al., 2003). The common characteristics of Alpinotype fissure quartz in Northern Greece (Dasoto, Thasos and Kavala) suggest common tectonometamorphic evolution during the exhumation of Southern Rhodope Core Complex. Future fluid inclusion, isotopic and geochronological studies will help better understand the genetic implications of alpinotype fissure minerals in Thasos Island and the broad Rhodope complex. Some fissure minerals on Thasos can be considered as gemstones. Alternatively the areas hosting alpinotype fissures should be considered as a Geotope and protected by integrating in a mineralogical Geopark under promotion of sustainable development in the area.

$\underline{\text { XLVII. No } 1-475}$ 


\section{References}

Brun J.P. and Sokoutis D. 2007. Kinematics of the Southern Rhodope Core Compex (North Greece), Int. J. Earth Sci., 96, 1079-1099.

Cathlelineau M. 1988. Cation size occupancy in chlorites and illites as a function of temperature, Clay Minerals, 23, 471-485.

Fornadel A.P., Spry P.G., Melfos V., Vavelidis M. and Voudouris P. 2011. The Palea Kavala $\mathrm{Bi}-\mathrm{Te}-\mathrm{Sb} \pm \mathrm{Au}$ district: a reduced intrusion-related system, northeastern Greece, Ore Geology Reviews, 39, 119-133.

Heijboer T.C. 2006. Origin and pathways of pro- and retrograde fluids, PTt paths and fluidmineral equilibria from Alpine veins of the Central Alps: Case studies of the Fibbia and Amsteg area, Unpubl. PhD thesis, University Basel, 173 pp.

Heijboer T.C., Mullis J. and de Capitani C. 2003. Prograde and retrograde fluid evolution and vein mineralization from tha southern Gotthard Massif, Switzerland, $E G S-A G U$ EUG, 6-11 April 2003, Abstract 4946.

Kandutsch G. and Wachtler M. 2000. Die Kristallsucher-Ein Gang durch die Jahrmillionen, Band 2, Christian Weise Verlag Munchen, 160 pp.

Koenigsberger J.G. 1972. Die zentralalpinen Minerallagerstaetten, Basel, 351 pp.

Maneta V. and Voudouris P. 2010 Quartz megacrysts in Greece: Mineralogy and environment of formation, Bull. Geol. Soc. Greece, XLIII, 685-696

Melfos V. and Voudouris P. 2006. Fluid inclusions and O-isotopes of an amethyst and smoky quartz occurrence in Kato Nevrokopi, Rhodope massif, Northern Greece, $11^{\text {th }}$ Int. Conf. Experimental Mineralogy, Petrology and Geochemistry, Abstract 50.

Melfos V., Voudouris P., Vavelidis M. and Spry P. 2008. Microthermometricresults and formation conditions of a new intrusion-related $\mathrm{Bi}-\mathrm{Te}-\mathrm{Pb}-\mathrm{Sb} \pm \mathrm{Au}$ deposit in the Kavala pluton, Greece, Proc. XIII Inter. Con. Thermobarogeochemistry, 2, 165-168.

Mullis J. 1975. Growth conditions of quartz crystals from Val d'Illiez (Valais, Switzerland), Schweiz. Miner. Petr. Mitt., 55/3, 419-430.

Mullis J. 1988. Rapid subsidence and upthrusting in the northern Apennines deduced by fluid inclusion studies in the quartz crystals from Porreta Terme, Schweiz. Miner. Petr. Mitt., 68, 157-170.

Mullis J. 1996. P-T-t path of quartz formation in extensional veins of the central Alps, Schweiz. Miner. Petr. Mitt., 76, 159-164.

Mullis J., Dubessy J., Poty B. and O’Neil J. 1994. Fluid regimes during late stages of a continental collision: physical, chemical and stable isotope measurements of fluid inclusions in fissure quartz from a geotraverse through the Central Alps, Switzerland, Geochim. Cosmochim. Acta, 58, 2239-2267.

Mullis J., Vennemann T. and O’Neil J. 2001. Deep percolating meteoric waters in the central Alps, EUG XI, Strasbourg, Abstract, 6(1), 279.

Niedermayer G. 1993. Alpine Kluefte, Mineralien Welt, 6, 57-59.

Stalder H.A. 1964. Petrographische und mineralogische Untersuchungen im Grimselgebiet (Mittleres Aarmassiv), Schweiz. Miner. Petr. Mitt., 44/1, 187-398.

Stalder H.A. and Touray J.C. 1970. Fensterquarze mit Methan-Einschlüssen aus dem westlichen Teil der schweizerischen Kalkalpen, Schweiz. Miner. Petr. Mitt., 50/1, 109130.

Tsolakos A., Voudouris P. and Papanikitas A. 2008. Kristallklüfte in Attika und auf Euböa. Bergkristall, Amethyst und Rauchquarz aus Griechenland, Lapis, 5, 36-39.

Voudouris P. 2005. Minerals of Eastern Macedonia and Western Thrace: Geological framework and environment of formation, Bull. Geol. Soc. Greece, 37, 62-77.

Voudouris P., Katerinopoulos A. and Melfos V. 2004. Alpine-type fissure minerals in Greece, Documenta Naturae, 151, 23-45.

Wendel W. and Kapelas Ch. 1997. Alpine smoky quartz from Attica, Lapis, 22/3, 35-37. 